\title{
Productive performance of confined young bulls fed proportions of 'Mulato II' grass silage in the diet
}

\author{
Regis Luis Missio(1), Emerson Alexandrino(2), Darlene Pereira da Silva(2), Joaquim José de Paula Neto (2), \\ José Messias de Rezende ${ }^{(2)}$, André Augusto Marinho Silva ${ }^{(2)}$ and Denise Vieira da Silva ${ }^{(2)}$
}

\begin{abstract}
(1)Universidade Tecnológica Federal do Paraná, Departamento de Agronomia, Via do Conhecimento, Km 01, CEP 85503-390 Pato Branco, PR, Brazil. E-mail: regisluismissio@gmail.com (2)Universidade Federal do Tocantins, Escola de Medicina Veterinária e Zootecnia, BR-153, Km 112, Zona Rural, s/no, CEP 77804-970 Araguaína, TO, Brazil. E-mail: e_alexandrino@yahoo.com.br, darlene_zootec@hotmail.com, jneto@zootecnista.com.br, messyas10@hotmail.com, andre_augusto89@hotmail.com, denise.v.silva@live.com
\end{abstract}

Abstract - The objective of this work was to evaluate the performance of young Nellore bulls and of young dual-purpose dairy bulls fed proportions of 'Mulato II' grass silage (400 and $\left.100 \mathrm{~g} \mathrm{~kg}^{-1}\right)$, in diets with high levels of concentrate, as well as to evaluate the cost of this feed. Sixteen young Nellore bulls and 16 young dairy crossbred bulls were used, with initial average weight of $380.69 \pm 10.45$ and $376.94 \pm 17.16 \mathrm{~kg}$, respectively, and average initial age of 24 months. A completely randomized experimental design was carried out in a $2 \times 2$ factorial arrangement. The highest silage proportion caused a $13 \%$ increase in dry matter intake (percentage of body weight) and a 19.7\% decrease in dry matter digestibility of the diet, but it did not alter the intake of total digestible nutrients, nor the average daily gain or carcass characteristics. Nutrient intake and digestibility, average daily gain, and carcass characteristics (except conformation) did not change due to the genetic group of animals. Feed conversion was $18.3 \%$ better in young dairy bulls. In diets with high levels of concentrate, the proportion of $400 \mathrm{~g} \mathrm{~kg}^{-1}$ of 'Mulato II' grass silage, in comparison with that of $100 \mathrm{~g} \mathrm{~kg}^{-1}$, does not affect the productive performance, nor the main carcass characteristics of economic interest of confined young bulls, but reduces feeding costs.

Index terms: Brachiaria, Urochloa, carcass weight, forage hybrid, subcutaneous fat thickness, weight gain.

\section{Desempenho produtivo de tourinhos confinados e alimentados com proporções de silagem de capim 'Mulato II' na dieta}

Resumo - O objetivo deste trabalho foi avaliar o desempenho produtivo de tourinhos Nelore e de mestiços de origem leiteira de dupla aptidão, alimentados com proporções de silagem de capim 'Mulato II' $\left(100 \mathrm{e} 400 \mathrm{~g} \mathrm{~kg}^{-1}\right)$, em dietas com altas proporções de concentrado, bem como avaliar o custo dessa alimentação. Utilizaram-se

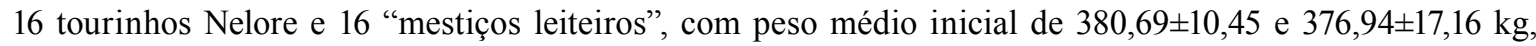
respectivamente, e idade média inicial de 24 meses. Utilizou-se o delineamento experimental inteiramente casualizado, em arranjo fatorial $2 \times 2$. A maior proporção de silagem ocasionou aumento de $13 \%$ do consumo de matéria seca (percentagem do peso corporal) e redução de 19,7\% da digestibilidade da matéria seca da dieta, mas não alterou o consumo de nutrientes digestíveis totais, nem o ganho médio diário e as características de carcaça. $\mathrm{O}$ consumo e a digestibilidade dos nutrientes, o ganho médio diário e as características de carcaça (exceto conformação) não se alteraram com o grupo genético dos animais. A conversão alimentar foi 18,3\% melhor nos tourinhos mestiços leiteiros. Em dietas com alta proporção de concentrado, a proporção de 400 $\mathrm{g} \mathrm{kg}^{-1}$ de silagem de capim 'Mulato II', em relação à de $100 \mathrm{~g} \mathrm{~kg}^{-1}$, não altera o desempenho produtivo nem as principais características de carcaça de interesse econômico de tourinhos confinados, mas reduz o custo com alimentação.

Termos para indexação: Brachiaria, Urochloa, peso de carcaça, forrageira híbrida, espessura de gordura, ganho de peso.

Introduction

Brazil has the conditions needed to increase beef production, in order to meet the increased worldwide demand for animal protein (Anualpec, 2014). In this context, the use of dairy males, which are usually sacrificed at birth or sold, is an alternative to increase both meat production and income generation. However, since the feeding of non-sacrificed animals is usually deficient, there is high mortality during 
the rearing period or delayed animal growth, which increases the age at slaughter and compromises important characteristics such as carcass yield, muscle development, and meat quality.

The feedlot is an advantageous management option for the termination of "dairy males", because it avoids competition for pasture areas that are normally intended for dairy cows. However, high feeding costs have made feedlot usage little attractive. These costs can be reduced by incorporating higher proportions of silage, preferably high-quality bulky ones, in the diets, but this is not always possible because of the agricultural potential of production systems. Tropical grass species are an alternative food source, but greater amounts of concentrate are required in the diet, which can affect the profit margin due to concentrate costs, leading to higher production costs in the feedlot when the cost of animal acquisition is not considered (Cruz et al., 2014; Silva et al., 2014).

'Mulato II' (CIAT 36087), commercial name Convert HD364, is a tetraploid (4n) hybrid of the genus Urochloa (Syn. Brachiaria), obtained from crossings between $U$. ruziziensis $\mathrm{x} U$. decumbens $\mathrm{x}$ $U$. brizantha by Centro Internacional de Agricultura Tropical (CIAT). Recently introduced in Brazil (Argel et al., 2007), it has spiked the interest of the production sector. According to Vendramini et al. (2012), 'Mulato II' grass stands out as a promising plant, since it associates productivity and acceptability by grazing beef cattle, besides presenting better nutritional value than other tropical grasses. Several studies have been performed due to the lack of information about this forage (Vendramini et al., 2014; Pequeno et al., 2015). However, these studies have prioritized management information, whereas information on the nutritional value of this forage, especially when conserved for cattle feed, remain incipient.

The animal component is also relatively important for feedlot termination. According to Putrino et al. (2007), zebu animals are less adapted than taurine animals to high levels of concentrate, which may limit the productive performance of that genotype. The use of crossbred dairy zebu and taurine breeds is an alternative to overcome this problem, since, during their evolution, dairy breeds were adapted to higher amounts of concentrated food in their diets.

The objective of this work was to evaluate the performance of young Nellore bulls and of young dual- purpose dairy bulls fed proportions of 'Mulato II' grass silage (400 and $100 \mathrm{~g} \mathrm{~kg}^{-1}$ ), in diets with high levels of concentrate, as well as to evaluate the cost of this feed.

\section{Materials and Methods}

The study was carried out at the college of veterinary medicine and animal science of Universidade Federal de Tocantins, in the state of Tocantins, Brazil $\left(07^{\circ} 11^{\prime} 28^{\prime \prime} \mathrm{S}, 48^{\circ} 12^{\prime} 26^{\prime \prime} \mathrm{W}\right)$. The experimental procedures were approved by the ethics committee on animal testing of the university, under the number 23101.000785/2.014-91. Sixteen Nellore bulls and 16 crossbred dairy bulls (eight Holstein $\times$ Gir and eight Holstein $\times$ Guzerá), with initial average weights of $381 \pm 10$ and $377 \pm 17 \mathrm{~kg}$, respectively, and initial average ages, estimated based on dental examination, of 25 and 23 months, respectively, were used. After parasitic diseases were controlled, the animals were confined in partially covered pens $\left(16 \mathrm{~m}^{2}\right)$ with concrete floors, equipped with waterers and feeders; each pen contained two animals belonging to the same genetic group. Before the 63-day experimental period, the animals were adapted to the facilities, diets, and food management regimens for 15 days.

Two diets were formulated based on the cattle requirements during the growth and finishing periods (Table 1), considering a dry matter intake of $24 \mathrm{~g} \mathrm{~kg}^{-1}$ body weight (Nutrient..., 1996). Treatments were composed of two proportions of 'Mulato II' grass silage (100 and $400 \mathrm{~g} \mathrm{~kg}^{-1}$ ) and two genetic groups (Nellore and dairy crossbred). The concentrated fraction was composed of corn meal, soybean meal, mineral mix, limestone, urea, white salt, and ammonium sulfate. Food prices were quoted in 2012, and the feeding cost was estimated based on dry matter intake.

At the beginning and end of the experimental period, after solid and liquid fasting for 14 to 16 hours, animals were weighed and evaluated regarding body condition, using the scores: 1 , very thin; and 5, very fat. Food intake was measured daily by weighing food and leftovers. Animals were fed ad libitum, and the leftovers were maintained at approximately $10 \%$. Food was provided twice per day (at 08h00 and 14h00). Food and leftover samples were collected weekly, then pre-dried in a greenhouse with forced air ventilation at $55^{\circ} \mathrm{C}$, for 72 hours, and processed in a Willey-type mill with a 1-mm 
sieve. Subsequently, the chemical compositions of food and diets were determined (Table 2).

Dry matter, mineral matter, crude protein, and ethereal extract contents were determined according to Cunniff (1995). Contents of neutral detergent fiber, acid detergent fiber, and lignin were obtained as in Van Soest et al. (1991), and neutral detergent fiber was corrected for mineral matter and protein. Total carbohydrates, non-fibrous carbohydrates, and total digestible nutrients were determined according to Sniffen et al. (1992), as: total carbohydrates $=100$ (crude protein + ethereal extract + mineral matter); nonfibrous carbohydrates $=100$ - $($ crude protein + ethereal extract + mineral matter + neutral detergent fiber); and total digestible nutrients $=$ digestible crude protein +

Table 1. Composition of the experimental diets.

\begin{tabular}{|c|c|c|}
\hline \multirow{2}{*}{ Items ( $\mathrm{g} \mathrm{kg}^{-1}$ dry matter) } & \multicolumn{2}{|c|}{ Silage proportion } \\
\hline & $100 \mathrm{~g} \mathrm{~kg}^{-1}$ & $400 \mathrm{~g} \mathrm{~kg}^{-1}$ \\
\hline 'Mulato II' grass silage & 105.25 & 403.06 \\
\hline Corn meal & 767.29 & 437.24 \\
\hline Soybean meal & 85.89 & 122.38 \\
\hline Mineral mix $^{(1)}$ & 16.10 & 16.71 \\
\hline Limestone & 11.16 & 7.16 \\
\hline Urea $(45 \% \mathrm{~N})$ & 8.10 & 7.16 \\
\hline White salt & 5.37 & 5.42 \\
\hline Ammonium sulfate & 0.84 & 0.87 \\
\hline
\end{tabular}

${ }^{(1)}$ Composition $\left(\mathrm{g} \mathrm{kg}^{-1}\right): 150 \mathrm{Na}, 118 \mathrm{Ca}, 90 \mathrm{P}, 7 \mathrm{Mg}, 12 \mathrm{~S}, 10 \mathrm{~N}, 3.6 \mathrm{Zn}, 1.73$ $\mathrm{Cu}, 0.2 \mathrm{Co}, 0.1 \mathrm{Mn}, 0.015 \mathrm{I}$, and $0.002 \mathrm{Se}$. digestible fiber in neutral detergent + digestible nonfibrous carbohydrates $+(2.25 \times$ digestible ethereal extract).

The digestibility assay was performed for five consecutive days, and manual collection of $300 \mathrm{~g}$ of feces per day occurred during spontaneous defecation. To estimate dry matter excretion, non-digestible neutral detergent fiber was used as an internal control. The non-digestible fiber contents in neutral detergent of feces, food, leftovers, and diet samples were obtained after in situ incubation in two dairy bulls fed diets containing $300 \mathrm{~g} \mathrm{kg-1}$ of 'Mulato II' grass silage for 240 hours (Casali et al., 2008). Fecal production (FP), in kilogram per day, was obtained using the formula: $\mathrm{FP}=$ (intake of non-digestible neutral detergent fiber/ concentration of non-digestible neutral detergent fiber in the feces) $\times 100$. The apparent digestibility (AD) was calculated by the formula: $\mathrm{AD}\left(\mathrm{g} \mathrm{kg}^{-1}\right)=[$ (nutrient ingested - nutrient excreted)/nutrient ingested].

After a fast of 14 to 16 hours, animals with average body weights of $480 \mathrm{~kg}$ were slaughtered in an abattoir refrigerator under the supervision of the federal inspection service. After slaughter, carcasses were identified, divided in half, weighed to determine the warm carcass yield, washed, and cooled for 24 hours at $-2^{\circ} \mathrm{C}$. After cooling, carcasses were weighed to determine the cold carcass yield, and were evaluated with regard to conformation (1-3, low; 4-6, bad; 7-9, regular; 10-12, good; 13-15, very good; and 16-18, high) and to physiological maturity (1-3, above 8 years

Table 2. Chemical composition and costs of food and diets.

\begin{tabular}{|c|c|c|c|c|c|}
\hline \multirow[t]{2}{*}{ Item $^{(1)}$} & \multicolumn{3}{|c|}{ Food } & \multicolumn{2}{|c|}{ Silage proportions } \\
\hline & Silage & Corn meal & Soybean meal & $100 \mathrm{~g} \mathrm{~kg}^{-1}$ & $400 \mathrm{~g} \mathrm{~kg}^{-1}$ \\
\hline Dry matter (DM, g) & 227.21 & 885.67 & 899.33 & 822.28 & 626.20 \\
\hline Mineral matter $\left(\mathrm{g} \mathrm{kg}^{-1} \mathrm{DM}\right)$ & 78.30 & 19.20 & 68.20 & 61.45 & 77.59 \\
\hline Crude protein $\left(\mathrm{g} \mathrm{kg}^{-1} \mathrm{DM}\right)$ & 60.40 & 105.70 & 452.87 & 149.13 & 146.11 \\
\hline Ether extract $\left(\mathrm{g} \mathrm{kg}^{-1} \mathrm{DM}\right)$ & 8.21 & 45.00 & 18.00 & 36.94 & 25.19 \\
\hline $\mathrm{NDF}\left(\mathrm{g} \mathrm{kg}^{-1} \mathrm{DM}\right)$ & 728.20 & 194.30 & 202.40 & 243.11 & 403.23 \\
\hline NDFap $\left(\mathrm{g} \mathrm{kg}^{-1} \mathrm{DM}\right)$ & 682.17 & 172.02 & 179.41 & 219.20 & 372.13 \\
\hline $\mathrm{ADF}\left(\mathrm{g} \mathrm{kg}^{-1} \mathrm{DM}\right)$ & 414.60 & 57.30 & 80.60 & 94.53 & 202.03 \\
\hline $\operatorname{Lignin}\left(\mathrm{g} \mathrm{kg}^{-1} \mathrm{DM}\right)$ & 86.88 & 2.49 & 3.09 & 11.32 & 36.48 \\
\hline Total carbohydrates $\left(\mathrm{g} \mathrm{kg}^{-1} \mathrm{DM}\right)$ & 853.09 & 830.10 & 460.93 & 766.30 & 763.21 \\
\hline Non-fibrous carbohydrates ( $\left.\mathrm{g} \mathrm{kg}^{-1} \mathrm{DM}\right)$ & 124.89 & 635.80 & 258.53 & 523.19 & 359.97 \\
\hline TDN ( $\left.\mathrm{g} \mathrm{kg}^{-1} \mathrm{DM}\right)$ & 502.17 & 882.36 & 817.76 & 800.14 & 688.31 \\
\hline Metabolizable energy ( $\left.\mathrm{kcal} \mathrm{kg}^{-1} \mathrm{DM}\right)$ & 1.81 & 3.18 & 2.95 & 2.89 & 2.48 \\
\hline Cost $\left(\mathrm{R} \$ \mathrm{~kg}^{-1} \mathrm{DM}\right)$ & 0.22 & 0.56 & 1.78 & 0.65 & 0.59 \\
\hline
\end{tabular}

${ }^{(1)}$ NDF, neutral detergent fiber; NDFap, NDF corrected for ash and protein; ADF, acid detergent fiber; and TDN, total digestible nutrients. 
of age; 4-6, from 5.5 to 8 years of age; 7-9, from 4 to 5.5 years of age; $10-12$, from 2.5 to 4 years of age; and 13-15, less than 2.5 years of age), according to the method described by Müller (1987). The carcass yield $\left(\mathrm{g} \mathrm{kg}^{-1}\right)$ was determined by dividing the warm and cold carcass weights by the initial body weight (weight at the farm). Drip loss (DL) was determined using the following formula: DL $\left(\mathrm{g} \mathrm{kg}^{-1}\right)=$ (hot carcass weight - cold carcass weight)/hot carcass weight $\times 1,000$. The section between the eleventh and twelfth rib was removed from the right half of the carcass, in order to determine the area of the longissimus dorsi muscle. At the same anatomical site, the subcutaneous fat thickness was determined from the arithmetic average of three observations.

The experimental design was completely randomized, with treatments in a $2 \times 2$ factorial arrangement (silage proportions $\mathrm{x}$ genetic group). Four replicates were used for intake and feed conversion data, and eight replicates for the other variables. Data were subjected to the analysis of variance, at $5 \%$ probability.

\section{Results and Discussion}

Regarding the analyzed variables, there were no interactions between silage proportions and genetic groups. Therefore, the variation factors were addressed separately. The intake of dry matter and other nutrients did not change based on the genetic group (Table 3). However, differences in dry matter intake between beef and dairy cattle have been reported. Rodríguez et al. (1997) observed greater intake by Holstein dairy males when compared with young Nellore bulls, which could be attributed to the specific selection for milk production, requiring greater food intake and, consequently, greater development of the gastrointestinal tract.

The increase in the proportion of 'Mulato II' grass silage in the diets resulted in an increase in dry matter intake (Table 3). This result differs from those obtained by other authors, who found that this variable frequently exhibited quadratic variation - with highest point for diets with $33 \%$ bulky material - and linear reduction, or remained constant as the proportion of silage in the diets increased (Missio et al., 2009; Restle et al., 2012). According to Restle et al. (2012), although there is no consensus, dry matter intake tends to increase when the content of forage in the diets is greater than that of the concentrate; however, when the concentrate fraction exceeds the forage fraction, dry matter intake tends to reach the inflection point of the curve, decreasing because digestible energy intake is increased and the energy demands of the animals are met.

The increase in intake in response to increased proportions of 'Mulato II' grass silage was associated with the reduction in the energy content in the diets (Table 2). Krehbiel et al. (2006), evaluating the upper limits of the energetic densities of diets for feedlot cattle finishing, found that dry matter intake decreased when the diets contained between 2.7 and $3.3 \mathrm{Mcal}$ $\mathrm{kg}^{-1}$ dry matter metabolizable energy; however, energy intake remained constant. In the present study, the metabolizable energy content decreased from 2.89 to $2.48 \mathrm{Mcal} \mathrm{kg}^{-1}$ dry matter as the silage proportion increased, which is an indication that intake was limited by the energetic density of the diets with a lower silage proportion. However, in the diets with the highest proportion of 'Mulato II' grass silage, animals had to increase their food intake to maintain energy intake and to meet their energy requirements.

The intake of crude protein, neutral detergent fiber, and non-fibrous carbohydrates ( $\mathrm{g} \mathrm{kg}^{-1}$ body weight) increased with the increased proportions of 'Mulato II' grass silage in the diets (Table 3), which can be attributed to an increase in dry matter intake. The greater amount of detergent fiber from 'Mulato II' grass silage contributed to an increase in neutral detergent fiber intake in response to increased proportions of silage in the diets. It should be noted that the intake of neutral detergent fiber did not limit dry matter intake, as it did not reach the values (11-13 $\mathrm{g} \mathrm{kg}^{-1}$ body weight) considered restricting to intake due to the filling of the reticulorumen (Mertens, 1994).

Total digestible nutrient intake was not altered by the genetic group or the proportion of silage in the diet (Table 3). These results showed the nutritional potential of 'Mulato II' grass silage, which allowed meeting the energy demand of the animals, despite the reduction of apparent digestibility in diets with increased silage proportions. This reduction paralleled a reduction in dry matter digestibility and total carbohydrates. Moreover, it can be attributed to the cumulative effect of reduced digestibility in other food fractions, especially with increased content of neutral detergent 
fiber from 'Mulato II' grass silage. This content, although high, was lower than the one in the silage of the main tropical grasses, as observed by Oliveira et al. (2015).

The genetic group and the proportion of 'Mulato II' grass silage in the diets did not alter animal performance or the body condition score at slaughter (Table 4), which can be explained by the similar energy intake. These results are not in agreement with those obtained by Missio et al. (2009), who found a reduction in average daily gain as the proportion of corn silage in the diets of Charolais $\times$ Nellore bulls increased, which was attributed to decreased energy intake. Restle et al. (2012) showed that the effect of silage proportion on animal performance is related to the quality of the used silage, i.e.: when the silage was of poor quality, the productive performance was reduced as the proportion of silage in the diets increased; but, when the silage had high quality, it was not altered.

Feed conversion was higher (18.3\%) in dairy crossbred bulls, but it was not altered by the proportions of 'Mulato II' grass silage in the diets (Table 4). These results corroborate those of Araújo et al. (2011), who evaluated Zebu heifers and Zebu $\times$ Holstein crossbreed heifers in feedlots, but did not observe differences in feed conversion and in weight gain. According to Roma Júnior et al. (2008), the superior feed conversion found in dairy crossbred bulls is a consequence of the heterosis resulting from crossing zebu and taurine breeds. However, the similar feed conversions for the different proportions of 'Mulato II' grass silage observed in the present study were not reported by Restle et al. (2012). These authors explain that the reduction of feed conversion in response to increased silage proportions is due to the reduced energy content in the diets, which leads to greater food intake in order to meet the demands related to weight gain. However, when high quality silage is used, feed conversion is generally not altered by the proportion of silage in the diets (Pereira et al., 2006).

The feeding cost was reduced by increasing the proportion of 'Mulato II' grass silage in the diets and it was not affected by the genetic group (Table 4). This reduction can be attributed to a reduction in the concentrated fraction of the diets, which has the highest cost (Table 2). However, when the feeding cost was analyzed regarding the average daily weight gain, no significant difference was detected, which is associated with increased dry matter intake due to

Table 3. Intake and digestibility of dry matter (DM) and nutrients of diets with two silage proportions (100 and $\left.400 \mathrm{~g} \mathrm{~kg}^{-1}\right)$ of 'Mulato II' grass fed to young Nellore bulls and dairy crossbreeds.

\begin{tabular}{|c|c|c|c|c|c|c|c|c|}
\hline \multirow[t]{2}{*}{ Item $^{(1)}$} & \multicolumn{2}{|c|}{100} & \multicolumn{2}{|c|}{400} & \multirow{2}{*}{$\begin{array}{l}\text { CV } \\
(\%)\end{array}$} & \multicolumn{3}{|c|}{ Sources of variation ${ }^{(2)}$} \\
\hline & Nellore & Crossbreeds & Nellore & Crossbreeds & & SP & GG & $\mathrm{SP} \times \mathrm{GG}$ \\
\hline & \multicolumn{8}{|c|}{ Intake } \\
\hline DM (kg per day) & 8.91 & 8.19 & 9.87 & 9.51 & 9.80 & 0.025 & 0.248 & 0.683 \\
\hline $\mathrm{DM}\left(\mathrm{g} \mathrm{kg}^{-1} \mathrm{BW}\right)$ & 20.97 & 19.24 & 22.91 & 22.34 & 7.48 & 0.008 & 0.175 & 0.480 \\
\hline CP (kg per day) & 1.27 & 1.10 & 1.54 & 1.54 & 12.49 & 0.001 & 0.331 & 0.318 \\
\hline $\mathrm{CP}\left(\mathrm{g} \mathrm{kg}^{-1} \mathrm{BW}\right)$ & 3.01 & 2.58 & 3.57 & 3.62 & 10.22 & $<0.001$ & 0.274 & 0.176 \\
\hline NDF (kg per day) & 2.24 & 1.99 & 3.39 & 3.26 & 12.07 & $<0.001$ & 0.274 & 0.714 \\
\hline $\mathrm{NDF}\left(\mathrm{g} \mathrm{kg}^{-1} \mathrm{BW}\right)$ & 5.27 & 4.67 & 7.87 & 7.66 & 10.45 & $<0.001$ & 0.247 & 0.567 \\
\hline NFC (kg per day) & 4.27 & 4.02 & 3.83 & 3.69 & 10.57 & 0.088 & 0.372 & 0.787 \\
\hline $\mathrm{NFC}\left(\mathrm{g} \mathrm{kg}^{-1} \mathrm{BW}\right)$ & 10.05 & 9.45 & 8.89 & 8.67 & 8.41 & 0.028 & 0.314 & 0.634 \\
\hline TDN (kg per day) & 6.19 & 5.96 & 6.36 & 6.53 & 9.91 & 0.253 & 0.919 & 0.528 \\
\hline \multirow[t]{2}{*}{ TDN ( $\left.\mathrm{g} \mathrm{kg}^{-1} \mathrm{BW}\right)$} & 14.56 & 13.99 & 14.78 & 15.36 & 8.16 & 0.208 & 0.992 & 0.356 \\
\hline & \multicolumn{8}{|c|}{ Digestibility } \\
\hline $\mathrm{DM}\left(\mathrm{g} \mathrm{kg}^{-1}\right)$ & 708.14 & 662.85 & 594.39 & 551.55 & 7.21 & $<0.001$ & 0.076 & 0.958 \\
\hline $\mathrm{CP}\left(\mathrm{g} \mathrm{kg}^{-1}\right)$ & 679.49 & 639.93 & 589.35 & 616.78 & 11.53 & 0.146 & 0.870 & 0.376 \\
\hline $\mathrm{NDF}\left(\mathrm{g} \mathrm{kg}^{-1}\right)$ & 576.68 & 576.72 & 505.54 & 537.33 & 11.96 & 0.118 & 0.636 & 0.637 \\
\hline $\mathrm{NFC}\left(\mathrm{g} \mathrm{kg}^{-1}\right)$ & 829.79 & 811.15 & 832.52 & 813.31 & 3.55 & 0.869 & 0.218 & 0.984 \\
\hline $\mathrm{TC}\left(\mathrm{g} \mathrm{kg}^{-1}\right)$ & 745.31 & 690.51 & 625.76 & 572.37 & 7.54 & $<0.001$ & 0.050 & 0.978 \\
\hline
\end{tabular}

${ }^{(1)} \mathrm{DM}$, dry matter; BW, body weight; CP, crude protein; NDF, neutral detergent fiber; NFC, non-fibrous carbohydrates; TDN, total digestible nutrients; and $\mathrm{TC}$, total carbohydrates. ${ }^{(2)} \mathrm{SP}$, silage proportion; and GG, genetic group. $\mathrm{CV}$, coefficient of variation. 
increased proportions of 'Mulato II' grass silage in the diets. The obtained results were consistent with those found by Missio et al. (2009), who reported that the feeding cost decreased with increased proportions of corn silage in the diets of feedlot bulls, due to the lower cost of the silage compared with that of the concentrate.

The carcass characteristics, except conformation, were not altered by variation factors (Table 5), which can be explained by the similar body weight and finishing of the animals at slaughter. These results are in alignment with those obtained by Missio et al. (2010), who observed that increased proportions of silage in diets did not alter most carcass characteristics, which was also attributed to similar body weights at slaughter. However, according to these researchers, increased proportions of corn silage in the diets increased age at slaughter, resulting in increased physiological maturity of the carcasses. In the present study, animals were slaughtered at similar ages (23-25 months), which accounted for the low variation observed in the values associated with physiological maturity and carcasses characteristics. The obtained results were consistent with those presented by Costa et al. (2007) and Rocha Júnior et al. (2010), which showed that dairy crossbred bulls with dual-purpose genotypes were similar regarding most carcass characteristics, compared with Nellore cattle. Carcass yield is one of the main exceptions, since this characteristic is usually enhanced in the Nellore breed, which is attributed to lower weights and to the filling of the gastrointestinal tract of Nellore cattle, in comparison with crossbred dairy bulls (Costa et al., 2007; Rocha Júnior et al., 2010).

The conformation of the carcasses was only altered by the genetic group of the animals, and it was superior in dual-purpose bulls (Table 5). These results can be attributed to the greater carcass compactness of the dual-purpose dairy crossbred bulls, compared with Nellore cattle, but this does not necessarily mean greater meat yield (Jorge et al., 1997). Carcass conformation or muscularity between dairy crossbred and Nellore cattle is controversial in the literature, because some authors (Costa et al., 2007) did not observe changes in this characteristic among these genetic groups, whereas others (Rocha Júnior et al., 2010) found higher muscle mass in Nellore carcasses. Despite this, it is widely known that cattle breeds specifically bred for milk production have lower muscularity than beef cattle, due to the different aims and selection pressures associated with the evolution of these biotypes (Albertí et al., 2008). However, dual-purpose dairy crossbred bulls have muscularity similar to that of specialized cattle breeds, especially in relation to zebu cattle, which have lower muscularity than European breeds (Oliveira et al., 2009; Nogalski, 2013; Silva et al., 2015). The results of the present study highlight the potential of dualpurpose dairy bulls for meat production and income supplementation of dairy farms.

Table 4. Performance and feeding costs of young Nellore bulls and dairy crossbreeds fed two proportions (100 and $400 \mathrm{~g}$ $\mathrm{kg}^{-1}$ ) of 'Mulato II' grass silage.

\begin{tabular}{|c|c|c|c|c|c|c|c|c|}
\hline \multirow[t]{2}{*}{ Item $^{(1)}$} & \multicolumn{2}{|c|}{100} & \multicolumn{2}{|c|}{400} & \multirow{2}{*}{$\begin{array}{l}\text { CV } \\
(\%)\end{array}$} & \multicolumn{3}{|c|}{ Sources of variation ${ }^{(2)}$} \\
\hline & Nellore & Crossbreeds & Nellore & Crossbreeds & & SP & GG & $\mathrm{SP} \times \mathrm{GG}$ \\
\hline & \multicolumn{8}{|c|}{ Performance } \\
\hline Initial body weight (kg) & 384.75 & 378.32 & 376.62 & 375.56 & - & - & - & - \\
\hline Final body weight (kg) & 476.10 & 486.05 & 473.64 & 478.88 & 3.69 & 0.123 & 0.291 & 0.222 \\
\hline ADG (kg per day) & 1.45 & 1.71 & 1.54 & 1.64 & 18.46 & 0.965 & 0.747 & 0.476 \\
\hline Initial body score (points) & 2.96 & 3.02 & 2.98 & 3.04 & - & - & - & - \\
\hline Final body score (points) & 3.58 & 3.56 & 3.60 & 3.76 & 3.75 & 0.123 & 0.291 & 0.222 \\
\hline Feed conversion $\left(\mathrm{kg} \mathrm{kg}^{-1}\right)$ & 6.14 & 4.79 & 6.41 & 5.80 & 15.28 & 0.010 & 0.589 & 0.576 \\
\hline Cost ( $\mathrm{R} \$$ per day) & 7.54 & 7.10 & 6.78 & 6.48 & 7.62 & 0.023 & 0.192 & 0.796 \\
\hline Cost $/ \mathrm{kg}$ of weight gain $(\mathrm{R} \$)$ & 4.29 & 4.26 & 4.68 & 4.05 & 14.01 & 0.765 & 0.296 & 0.349 \\
\hline
\end{tabular}

${ }^{(1)} \mathrm{ADG}$, average daily gain; and Feed conversion, $\mathrm{kg} \mathrm{DM} \mathrm{kg}^{-1}$ weight gain. ${ }^{(2)} \mathrm{SP}$, silage proportion; and GG, genetic group. CV, coefficient of variation. 
Table 5. Carcasses characteristics of young Nellore bulls and dairy crossbreeds fed two proportions $\left(100\right.$ and $\left.400 \mathrm{~g} \mathrm{~kg}^{-1}\right)$ of 'Mulato II' grass silage.

\begin{tabular}{|c|c|c|c|c|c|c|c|c|}
\hline \multirow[t]{2}{*}{ Item $^{(1)}$} & \multicolumn{2}{|c|}{100} & \multicolumn{2}{|c|}{400} & \multirow{2}{*}{$\begin{array}{l}\text { CV } \\
(\%)\end{array}$} & \multicolumn{3}{|c|}{ Sources of variation ${ }^{(2)}$} \\
\hline & Nellore & Crossbreeds & Nellore & Crossbreeds & & SP & GG & $\mathrm{SP} \times \mathrm{GG}$ \\
\hline $\mathrm{HCW}(\mathrm{kg})$ & 263.32 & 269.952 & 275.63 & 260.38 & 6.96 & 0.836 & 0.518 & 0.108 \\
\hline CCW (kg) & 262.00 & 268.52 & 274.40 & 258.72 & 6.77 & 0.839 & 0.478 & 0.092 \\
\hline $\mathrm{HCY}\left(\mathrm{g} \mathrm{kg}^{-1}\right)$ & 563.00 & 559.34 & 566.24 & 548.29 & 3.52 & 0.578 & 0.131 & 0.313 \\
\hline $\mathrm{CCY}\left(\mathrm{g} \mathrm{kg}^{-1}\right)$ & 560.18 & 556.56 & 563.72 & 544.81 & 3.45 & 0.551 & 0.108 & 0.269 \\
\hline $\mathrm{DL}\left(\mathrm{g} \mathrm{kg}^{-1}\right)$ & 4.99 & 4.92 & 4.41 & 6.35 & 25.67 & 0.769 & 0.518 & 0.491 \\
\hline $\mathrm{SF}(\mathrm{mm})$ & 3.88 & 4.06 & 4.22 & 3.25 & 28.36 & 0.554 & 0.317 & 0.144 \\
\hline PM (points) & 12.63 & 12.38 & 13.00 & 12.63 & 6.61 & 0.300 & 0.300 & 0.834 \\
\hline $\mathrm{CC}$ (points) & 10.00 & 11.13 & 11.00 & 11.50 & 8.64 & 0.051 & 0.021 & 0.356 \\
\hline LDA $\left(\mathrm{cm}^{2}\right)$ & 65.50 & 69.09 & 66.94 & 70.78 & 12.44 & 0.605 & 0.966 & 0.224 \\
\hline
\end{tabular}

${ }^{(1)} \mathrm{HCW}$, hot carcass weight; CCW, cold carcass weight; HCY, hot carcass yield; CCY, cold carcass yield; DL, drip loss; SF, subcutaneous fat thickness; PM, physiological maturity; CC, carcass conformation; and ALD, longissimus dorsi area. ${ }^{(2)} \mathrm{SP}$, silage proportion; and GG, genetic group. CV, coefficient of variation

\section{Conclusions}

1. The proportion of $400 \mathrm{~g} \mathrm{~kg}^{-1}$ of 'Mulato II' grass silage, in comparison with that of $100 \mathrm{~g} \mathrm{~kg}^{-1}$, in diets with a high proportion of concentrate, does not alter the productive performance or the main carcass characteristics of economic interest of feedlot bulls, but reduces the feeding cost.

2. Dual-purpose dairy crossbred bulls present productive potential and carcass quality similar to those of Nellore bulls subjected to feedlot finishing and fed diets with high proportions of concentrate.

\section{Acknowledgments}

To Conselho Nacional de Desenvolvimento Científico e Tecnológico $(\mathrm{CNPq}$, process No. 484306/2012-0), for financial support.

\section{References}

ALBERTÍ,P.; PANEA, B.; SAÑUDO, C.; OLLETA, J.L.; RIPOLL, G.; ERTBJERG, P.; CHRISTENSEN, M.; GIGLI, S.; FAILLA, S.; CONCETTI, S.; HOCQUETTE, J.F.; JAILLER, R.; RUDEL, S.; RENAND, G.; NUTE, G.R.; RICHARDSON, R.I.; WILLIAMS, J.L. Live weight, body size and carcass characteristics of young bulls of fifteen European breeds. Livestock Science, v.114, p.1930, 2008. DOI: 10.1016/j.livsci.2007.04.010.

ANUALPEC: anuário da pecuária brasileira. São Paulo: Instituto FNP, 2014. 378p.

ARAÚJO, W.A.; PAULINO, P.V.; MARCONDES, M.I.; CARVALHO, C.G.V.; SILVA, F.C. de O. Desempenho e características de carcaça de novilhas cruzadas de três grupos genéticos recebendo dietas à base de silagem de sorgo e milho. Ciência Animal Brasileira, v.12, p.101-107, 2011. DOI: 10.5216/ cab.v12i1.12229.

ARGEL, P.J.; MILES, J.W.; GUIOT, J.D.; CUADRADO, H.; LASCANO, C.E. Cultivar Mulato II (Brachiaria híbrida CIAT 36087): gramínea de alta qualidade e produção forrageira, resistente às cigarrinhas e adaptada aos solos tropicais ácidos e bem drenados. Cali: Centro Internacional de Agricultura Tropical, 2007. 22p.

CASALI, A.O.; DETMANN, E.; VALADARES FILHO, S. de C.; PEREIRA, J.C.; HENRIQUES, L.T.; FREITAS, S.G. de; PAULINO, M.F. Influência do tempo de incubação e do tamanho de partículas sobre os teores de compostos indigestíveis em alimentos e fezes bovinas obtidos por procedimentos in situ. Revista Brasileira de Zootecnia, v.37, p.335-342, 2008. DOI: 10.1590/S1516-35982008000200021.

COSTA, D.; ABREU, J.R. de.; MOURÃO, R. de C.; SILVA, J.C.G. da; RODRIGUES, V.C.; SOUSA, J.C.D. de; MARQUES, R.A.F. de S. Características de carcaça de novilhos inteiros Nelore e $F_{1}$ Nelore x Holandês. Ciência Animal Brasileira, v.8, p.685694, 2007.

CRUZ, R.S. da; ALEXANDRINO, E.; MISSIO, R.L.; RESTLE, J.; MELO, J.C.; PAULA NETO, J.J. de; NEIVA, J.N.M.; MENDES FILHO, G. de O.; SOUZA JÚNIOR, A. de; DUARTE, T.D. e; REZENDE, J.M. de; SILVA, A.A.M. Desempenho bioeconômico de tourinhos alimentados com níveis de concentrado e farelo do mesocarpo de babaçu. Semina: Ciências Agrárias, v.35, p.21592174, 2014. DOI: 10.5433/1679-0359.2014v35n4p2159.

CUNNIFF, P. (Ed.). Official methods of analysis of AOAC International. $16^{\text {th }}$ ed. Arlington: AOAC International, 1995. $2 \mathrm{v}$.

JORGE, A.M.; FONTES, C.A.A.; SOARES, J.E.; FREITAS, J.A.; RODRIGUES, L.R.R.; QUEIROZ, A.C.; RESENDE, F.D. Características quantitativas da carcaça de bovinos e bubalinos, abatidos em diferentes estágios de maturidade. Revista Brasileira de Zootecnia, v.26, p.1039-1047, 1997. 
KREHBIEL, C.R.; CRANSTON, J.J.; MCCURDY, M.P. An upper limit for caloric density of finishing diets. Journal of Animal Science, v.84, p.34-49, 2006. DOI: 2006.8413_supplE34x.

MERTENS, D.R. Regulation of forage intake. In: FAHEY JR., G.C. (Ed.). Forage quality, evaluation, and utilization. Madison: American Society of Agronomy, 1994. p.450-493.

MISSIO, R.L.; BRONDANI, I.L.; ALVES FILHO, D.C.; RESTLE, J.; ARBOITTE, M.Z.; SEGABINAZZI, L.R. Características da carcaça e da carne de tourinhos terminados em confinamento, recebendo diferentes níveis de concentrado na dieta. Revista Brasileira de Zootecnia, v.39, p.1610-1617, 2010. DOI: 10.1590/ S1516-35982010000700030.

MISSIO, R.L.; BRONDANI, I.L.; FREITAS, L. da S.; SACHET, R.H.; SILVA, J.H.S. da; RESTLE, J. Desempenho e avaliação econômica da terminação de tourinhos em confinamento alimentados com diferentes níveis de concentrado na dieta. Revista Brasileira de Zootecnia, v.38, p.1309-1316, 2009. DOI: 10.1590/S1516-3598200900070002.

MÜLLER, L. Normas para avaliação de carcaças e concurso de carcaças de novilhos. 2.ed. Santa Maria: Ed. da UFSM, 1987. $31 \mathrm{p}$.

NOGALSKI, Z; WRONSKI, M.; WIELGOSZ-GROTH, Z.; PURWIN, C.; SOBCZUK-SZUL, M.; MOCHOL, M.; POGORZELSKA, P. The effect of carcass conformation class (EUROP system) on the slaughter quality of young crossbred beef bulls and Holstein-Friesians. Annals of Animal Science, v.13, p.121-131, 2013. DOI: 10.2478/v10220-012-0064-9.

NUTRIENT requirements of beef cattle. $7^{\text {th }}$ ed. Washington: National Research Council, 1996. 242p.

OLIVEIRA, E.A. de; SAMPAIO, A.A.M.; FERNANDES, A.R.M.; HENRIQUES, W.; OLIVEIRA, R.V.; RIBEIRO, G.M. Desempenho e características de carcaça de tourinhos Nelore e Canchim terminados em confinamento recebendo dietas com cana-de-açúcar e dois níveis de concentrado. Revista Brasileira de Zootecnia, v.38, p.2465-2472, 2009. DOI: 10.1590/S151635982009001200024.

OLIVEIRA, Z.F. de; SANTANA JÚNIOR, H.A.; SANTANA, E.O.C.; FERREIRA, A.H.C.; PINHEIRO, A.A.; ABREU FILHO, G.; VIANA, P.T.; SANTOS, M. dos S. Silagem de gramíneas para bovinos. Revista Eletrônica Nutritime, v.12, p.3856-3864, 2015.

PEQUENO, D.N.L.; PEDREIRA, C.G.S.; SOLLENBERGER, L.E.; FARIA, A.F.G. de; SILVA, L.S. Forage accumulation and nutritive value of brachiariagrasses and Tifton 85 bermudagrass as affected by harvest frequency and irrigation. Agronomy Journal, v.107, p.1741-1749, 2015. DOI: 10.2134/agronj15.0115.

PEREIRA, D.H.; PEREIRA, O.G.; VALADARES FILHO, S. de. C.; GARCIA, R.; OLIVEIRA, A.P.; MARTINS, F.H.; VIANA, V. Consumo, digestibilidade dos nutrientes e desempenho de bovinos de corte recebendo silagem de sorgo (Sorghum bicolor (L.) Moench) e diferentes proporções de concentrado. Revista Brasileira de Zootecnia, v.35, p.282-291, 2006. DOI: 10.1590/ S1516-35982006000100036.

PUTRINO, S.M.; LEME, P.R.; SILVA, S.L. e; MANELLA, M.Q.; NOGUEIRA FILHO, J.C.M.; LIMA, C.G.; ALLEONI,
G.F. Digestibilidade aparente de dietas com níveis crescentes de concentrado em novilhos Brangus e Nelore. Arquivo Brasileiro de Medicina Veterinária e Zootecnia, v.59, p.406-413, 2007. DOI: 10.1590/S0102-09352007000200022.

RESTLE, J.; MISSIO, R.L.; RESENDE, P.L.P.; SILVA, N.L.Q.; VAZ, F.N.; BRONDANI, I.L.; ALVES FILHO, D.C.; KUSS, F. Silagem de híbridos de sorgo associado a percentagens de concentrado no desempenho de novilhos. Arquivo Brasileiro de Medicina Veterinária e Zootecnia, v.64, p.1239-1245, 2012. DOI: $10.1590 /$ S0102-09352012000500023.

ROCHA JÚNIOR, V.R.; SILVA, F.B. e; BARROS, R.C. de; REIS, S.T. dos; COSTA, M.D. da; SOUZA, A.S. de; CALDEIRA, L.A.; OLIVEIRA, T.S. de; OLIVEIRA, L.L. dos S. Desempenho e características de carcaça de bovinos Nelore e mestiços terminados em confinamento. Revista Brasileira de Saúde e Produção Animal, v.11, p.865-875, 2010.

RODRÍGUEZ, L.R.R.; FONTES, C.C. de A.; JORGE, A.M.; SOARES, J.E.; FREITAS, J.A. de. Digestibilidade de rações contendo quatro níveis de concentrado em bovinos (taurinos e zebuínos) e bubalinos. Revista Brasileira de Zootecnia, v.26, p.884-851, 1997.

ROMA JÚNIOR, L.C.; SAVASTANO JÚNIOR, H.; MARTELLO, L.S.; LEME, P.R.; PINHEIRO, M. da G. Produção de vitelos a partir de bezerros leiteiros mestiços e da raça Holandesa. Revista Brasileira de Zootecnia, v.37, p.1088-1093, 2008. DOI: 10.1590/ S1516-35982008000600020.

SILVA, A.H.G. da; RESTLE, J.; MISSIO, R.L.; BILEGO, U.O.; FERNANDES, J.J. de R.; REZENDE, P.L. de P.; SILVA, R.M. da; PEREIRA, M.L.R.; LINO, F.A. Milheto em substituição ao milho na dieta de novilhos confinados. Semina: Ciências Agrárias, v.35, p.2077-2094, 2014. DOI: 10.5433/1679-0359.2014v35n 4 p2077.

SILVA, R.M. da; RESTLE, J.; MISSIO, R.L.; BILEGO, U.O.; PACHECO, P.S.; REZENDE, P.L. de P.; FERNANDES, J.J. de R.; SILVA, A.H.G. da; PÁDUA, J.T. Características de carcaça e carne de novilhos de diferentes predominâncias genéticas alimentados com dietas contendo níveis de substituição do grão de milho pelo grão de milheto. Semina: Ciências Agrárias, v.36, p.943-960, 2015. DOI: 10.5433/1679-0359.2015v36n2p943.

SNIFFEN, C.J.; O'CONNOR, J.D.; VAN SOEST, P.J.; FOX, D.G.; RUSSELL, J.B. A net carbohydrate and protein system for evaluating cattle diets: II. Carbohydrate and protein availability. Journal of Animal Science, v.70, p.3562-3577, 1992. DOI: 10.2527/1992.70113562x.

VAN SOEST, P.J.; ROBERTSON, J.B.; LEWIS, B.A. Methods for dietary fiber, neutral detergent fiber, and nonstarch polysaccharides in relation to animal nutrition. Journal of Dairy Science, v.74, p.3583-3597, 1991. DOI: 10.3168/jds. S0022-0302(91)78551-2.

VENDRAMINI, J.M.B.; SOLLENBERGER, L.E.; LAMB, G.C.; FOSTER, J.L.; LIU, K.; MADDOX, M.K. Forage accumulation, nutritive value, and persistence of 'Mulatto II' brachiariagrass in Northern Florida. Crop Science, v.52, p.914-922, 2012. DOI: 10.2135/cropsci2011.06.0338. 
VENDRAMINI, J.M.B.; SOLLENBERGER, L.E.; SOARES, A.B.; SILVA, W.L. da; SANCHEZ, J.M.D.; VALENTE, A.L.; AGUIAR, A.D.; MULLENIX, M.K. Harvest frequency affects herbage accumulation and nutritive value of brachiaria grass hybrids in Florida. Tropical Grasslands - Forrajes Tropicales, v.2, p.197-206, 2014.

Received on March 27, 2016 and accepted on August 8, 2016 